\title{
The Physical Consequences of Fiscal Flexibility: Sovereign Credit and Physical Integrity Rights
}

\author{
K. Chad Clay \\ Department of International Affairs \\ University of Georgia \\ kcclay@uga.edu \\ Matthew R. DiGiuseppe \\ Department of Political Science \\ University of Mississippi \\ mrdigius@olemiss.edu
}

\begin{abstract}
Leaders are assumed to face fiscal constraints on their ability to remain in office by providing a competitive distribution of public and/or private goods. However, many leaders can relax this constraint by borrowing on sovereign credit markets. We argue that states with the fiscal flexibility offered by favorable credit terms have the resources necessary to (1) respond to citizen demands with policies other than widespread repression and (2) avoid agency loss that may result in unauthorized repression by state agents. Empirical analyses indicate that creditworthy states have greater respect for physical integrity rights and are less likely to suffer diminished respect for those rights when facing violent dissent or negative shocks to government revenues.
\end{abstract}

Forthcoming in the British Journal of Political Science 
A government's financial resources influence almost every aspect of political life within a country's borders, and a state's respect for human rights is no exception. ${ }^{1}$ A core finding of the human rights research program is that government violations of physical integrity rights, i.e. "the entitlements individuals have in international law to be free from arbitrary physical harm and coercion by their government," are prompted by internal threats to the status quo. ${ }^{3}$ Yet, widespread repression does not necessarily follow dissent; some governments have other viable policy options at their disposal for the reduction of dissent, many of which are likely to be more effective than widespread repression. ${ }^{4}$ However, those strategies that pose the least harm to physical integrity rights, while also preserving a government's hold on power, tend to require the largest financial commitments and at least some measure of fiscal flexibility in order to enact them. As such, appreciating the financial constraints imposed on governments can improve our understanding of the extent of government violations of physical integrity.

Existing human rights research frequently points to correlations between economic variables and respect for physical integrity rights, but such correlations are often attributed to increased demands stemming from economic grievances in economically disadvantaged countries, leaving the state with few alternatives aside from repression for dealing with those demands. ${ }^{5}$ Such work has inspired other studies exploring the effects of foreign direct investment or trade on government respect for physical integrity, with the theoretical linkage typically being the effect of such indicators on development, scarcity, and citizen demands. ${ }^{6}$ While such studies provide important insights regarding the relationship between globalization, economic development, and human rights, they say little about how the government's economic resources influence government violations of human rights. Some

\footnotetext{
${ }^{1}$ The authors would like to thank David Cingranelli, Amanda Murdie, Colin Barry, members of the Binghamton University World Politics Workshop and three anonymous reviewers for their comments and suggestions. Replication data and a supplementary appendix can be found at http://thedata.harvard.edu/dvn/dv/BJPols.

2 Cingranelli and Richards 1999, 407.

${ }^{3}$ Davenport 2007.

${ }^{4}$ Mason 2004; Poe 2004.

${ }^{5}$ Mitchell and McCormick 1988; Poe, Tate, and Keith 1999.

${ }^{6}$ Hafner-Burton 2005; Harrelson-Stephens and Callaway 2003; Mousseau and Mousseau 2008; Richards, Gelleny, and Sacko 2001.
} 
research has begun work toward this end by exploring relationships between the various attributes of state revenues and government respect for physical integrity rights. ${ }^{7}$ Still, much work remains to be done in delineating the many ways in which state resources are related to the state's ability to ensure that citizens' physical integrity rights are not violated.

In this paper, we focus on one particularly important source of resource variance that allows governments to engage in policies that would be beyond their immediate political or economic means if they were forced to rely on revenues alone: favorable sovereign credit terms. In short, we argue that access to affordable international capital increases leaders' ability to confront new challenges without forcing them to resort to widespread repression or the reallocation of resources previously dedicated to other survival-related purposes. In response to citizen demands, leaders with affordable access to sovereign credit have several different policy options, such as accommodation, investment in deterrent capability, or the strengthening of intelligence gathering capabilities, without imposing new taxes, introducing spending cuts, or engaging in distortionary monetary policy, each of which may weaken a leader's ability to remain in power. Further, leaders of creditworthy states have the ability to maintain their commitment to policies as government revenues fluctuate. As a result, leaders of states that hold the confidence of creditors have greater fiscal flexibility to manage domestic affairs and their political careers. In states that truly face fixed budget constraints, however, the political consequences of fiscal trade-offs serve to limit the government's ability to respond to new internal threats, while revenue shortfalls hamper the government's ability to maintain consistent policy. As such, fiscally constrained governments with little access to affordable international capital should be more likely to engage in high levels of repression, particularly during time periods of increased citizen demand or reduced revenue.

In the pages that follow, we discuss how sovereign creditworthiness differs from other sources of state capacity before moving forward to theorize about how creditworthiness grants leaders the fiscal flexibility to confront citizen demands with policy options other than widespread repression. All else being equal, we anticipate that creditworthy states should demonstrate greater respect for physical integrity rights. We then test the implications of our theory and discuss the results.

\footnotetext{
${ }^{7}$ Englehart 2009; Abouharb and Cingranelli 2006; Cingranelli, Fajardo-Heyward, and Filippov 2014; DeMerritt and Young 2013.
} 


\section{Fiscal Flexibility: The Unique Role of Sovereign Creditworthiness}

It is increasingly clear that fiscal policy and the sources of government revenue have important implications for the management of domestic political competition. Important studies have found that a state's natural resource wealth and other sources of non-tax income have numerous implications for political outcomes such as foreign policy, civil conflict, women's rights, and repression. ${ }^{8}$ Indeed, in recent years, researchers have uncovered many connections between the sources of government revenue and respect for physical integrity rights. For instance, DeMeritt and Young argue that when governments do not have to rely on their citizens for revenue, as they do when a state is highly dependent on taxes, they are less likely to respect their citizens' physical integrity rights. ${ }^{9}$ Indeed, they find that states with a high reliance on oil revenues tend to engage in higher levels of repression. Likewise, Cingranelli, Fajardo-Heyward, and Filippov demonstrate that states whose revenues are largely derived from taxes, as well as governments with larger total revenues, tend to demonstrate higher levels of respect for physical integrity rights. ${ }^{10}$ Related work demonstrates that greater fiscal and bureaucratic capacity is associated with greater respect for physical integrity rights. ${ }^{11}$

Sovereign creditworthiness, we contend, is conceptually distinct from these mechanisms. Unlike the proportion of revenue derived from tax or non-tax sources, sovereign borrowing has little bearing on the internal fiscal bargain between citizens and governments and thus, is inconsistent with the logic underpinning arguments linking non-tax revenue with greater repression. Sovereign credit increases fiscal flexibility but does not diminish the political power of taxpayers because loans are distributed with expectations of future repayment that will be dependent on a country's core economic and political structure. Because governments have an interest in maintaining creditworthiness, or at the very least will likely forfeit future funds if they repudiate debts, governments are still dependent on their original revenue sources, and as such, borrowed funds do little to detach governance from taxpayer interests.

\footnotetext{
${ }^{8}$ Bueno de Mesquita and Smith 2010; de Soysa and Neumayer 2007; Dunning 2005; Smith 2008.

${ }^{9}$ DeMeritt and Young 2013.

${ }^{10}$ Cingranelli, Fajardo-Heyward, and Filippov 2014.

11 Englehart 2009.
} 
In contrast to the effects of non-tax revenue, we contend that the additional fiscal resources available on sovereign credit markets help governments avoid the use of repression. While the role of private sovereign credit is largely overlooked in studies of human rights, there is some evidence that fiscal constraints have a salient impact on respect for human rights. For example, Abouharb and Cingranlli have provided evidence that fiscal constraints increase demands on the government and limit the government's ability to respect physical integrity rights, while Erikson and de Soysa argue that the decision to suspend loans from international financial institutions largely leads to increased repression. ${ }^{12}$ However, while these studies are suggestive of a potential relationship between fiscal constraints and physical integrity rights, their strict focus on loans received from the lenders of last resort, i.e. the World Bank and the International Monetary Fund, limit their applicability. Like conditional loans, a country's access to sovereign credit markets directly influences the available resources governments can marshal in response to new demands. However, if states hold favorable credit terms, loans with international banks or bond issuances provide a larger pool of resources, without attached policy concessions, than those available through official sources with such concessions.

Sovereign credit is also distinct in the manner in which it relates to the economic and political effects of fluctuations in a government's other revenue sources. Sovereign borrowing permits states to "smooth over" gaps in spending and revenue that arise when demand for spending outstrips revenue. In other words, governments can avoid new taxes or spending cuts when revenues drop or new expenses, such as a war, demand funding. Thus, sovereign credit serves not just as an augmentation of general government revenue but rather as a resource that can be tapped when shocks to revenue or spending emerge. Previous research indicates that this flexibility has salient economic and political effects.

Economically, borrowing allows states to avoid the economic distortions and uncertainty generated by consistently adjusting fiscal policy to correspond with revenue. This access to international capital aids long-run growth by allowing governments to maintain a stable provision of goods and stable tax rates as demands for new revenue increase. ${ }^{13}$ Then, these creditworthy states may repay their debts later when the budget is in surplus. States confronting demands for new revenue, or shocks to current revenue, that cannot borrow

\footnotetext{
12 Abouharb and Cingranlli 2006; Erikson and de Soysa 2009.

13 Barro 1979.
} 
must draw resources from other areas or leave government priorities unfunded. This can have dramatic economic and political consequences as the Latin American debt crisis in the 1980s and the more recent European debt crisis both illustrate. Furthermore, empirical evidence indicates that states that cannot borrow on international markets are more vulnerable to exogenous income shocks that then require austerity measures when countercyclical spending would prove most efficient. ${ }^{14}$ Given the economic advantages of credit, it is easy to see why many governments in both the developed and developing world have increasingly grown reliant on international capital for the everyday functioning of the state since the 1970 s. $^{15}$

Beyond the macroeconomic benefits of sovereign creditworthiness, research has also identified sovereign credit's political advantages. Typically, scholars assume that a leader's ability to manage their political career is constrained by a fixed amount of state resources. Increases in private or public goods must come at the expense of some other budgetary priority. As such, efforts to address one threat to a leader's tenure may increase the probability of threat from those satisfied with the previous fiscal distribution. However, this assumption fails to reflect the circumstances faced by creditworthy governments that can minimize immediate domestic trade-offs. If faced with a challenge to their tenure, affordable access to international capital allows leaders to raise resources to satiate political forces in the present while delaying the economic costs or pushing them upon their successors. ${ }^{16}$ In effect, they can expand their available resources to address new challenges in the most effective manner. As such, the ability to "smooth over" gaps in revenue and spending not only produces macroeconomic benefits but also has significant effects on the many political outcomes related to the distribution of state resources. Evidence consistent with the political influence of credit suggests that leaders face a harder time maintaining office when they see a drop in their credit rating, and, as their access to credit improves, they face a lower probability of armed rebellion, which is likely due to their improved ability to accommodate and deter opposition groups. ${ }^{17}$

\footnotetext{
14 Wibbels 2006.

15 World Bank 2012.

16 Alesina and Tabellini 1990; Easterly 2002; Oatley 2010.

17 DiGiuseppe and Shea ND; DiGiuseppe, Barry and Frank 2013.
} 
The macroeconomic and political benefits of sovereign creditworthiness speak to both its unique role in relation to traditional sources of fiscal capacity and its role in the politics of redistribution. Furthermore, sovereign creditworthiness exhibits substantial crosssectional and temporal variation and thus, provides a dynamic indicator of a state's ability to address new threats and maintain consistent policy in the face of fluctuations in revenue. In the section that follows, we theorize that these very abilities are responsible for leading some states to demonstrate greater respect for physical integrity rights than they would in the absence of access to affordable credit.

\section{Sovereign Creditworthiness \& Physical Integrity Rights}

Our argument may be summarized as follows: State leaders allocate resources in such a manner that maximizes the likelihood that they remain in power. In the absence of sovereign credit, meeting demands with costly policies will require the government to substantially reallocate resources away from the survival-maximizing equilibrium, which may prove to increase rather than diminish the level of threat. Since repression requires little reallocation of resources, leaders of states that lack access to affordable credit are likely to see it as their best option for dealing with threats. Further, even leaders that would prefer to limit their government's use of physical integrity rights abuse may find it difficult to do so in the absence of credit, as revenue fluctuations can leave them incapable of properly monitoring and rewarding government agents. Creditworthy governments, in contrast, can fall back on funds beyond state revenue and are thus capable of both engaging in a wider range of costly policies with far fewer political risks and maintaining control of their agents despite fluctuations in revenue. As such, leaders with access to more affordable credit should be expected to engage in fewer physical integrity rights violations.

\section{Sovereign Creditworthiness \& the Government Decision to Repress}

Our argument rests on the assumption that leaders are motivated primarily by selfinterest and that their chief concern is to ensure their own political survival. ${ }^{18}$ As such, we assume they constantly seek to maximize their own political power relative to the level of threat they face. ${ }^{19}$ Thus, if a government's leaders perceive their political positions are in jeopardy due to demands posed by internal opposition, an opposing political party, an

\footnotetext{
18 Bueno de Mesquita et al 2003.

19 Poe 2004.
} 
external rival, or some other threat, they should work to maintain their office. Government leaders may have several policy options at their disposal for dealing with perceived threats, but when dealing with internal threats, repression in the form of physical integrity rights abuse is one policy option that is almost always available.

While always available, violating physical integrity rights is not necessarily an optimal choice for managing threats to tenure. First, the widespread violation of physical integrity rights lends itself to many potential costs from international actors, such as economic sanctions, decreased foreign direct investment, reduced foreign aid, and negative international publicity from international non-governmental organizations. ${ }^{20}$ Second, and perhaps more importantly for the study at hand, widespread repression does not appear to be the most effective strategy for the long-term reduction of anti-government dissent. Indeed, the existing literature on repression and dissent suggests that the widespread abuse of physical integrity rights may very well lead to an increase in the likelihood of violent antigovernment activity. ${ }^{21}$

Given the external costs of repression and potential for greater dissent, why do we observe states utilizing repression in response to citizen demands? The answer lies in the relative costs of available policy options and the economic and political flexibility necessary to pay such costs. ${ }^{22}$ The decision to abuse physical integrity rights, particularly via indiscriminate means, in response to demands posed by actors outside of the leaders' winning coalition requires relatively little fiscal flexibility. In order to engage in the abuse of physical integrity rights, the state must merely order its existing agents to carry out the program of abuse designed by the government. Assuming the apparatus to carry out said repression exists, this requires little more than a re-prioritization of agents' activities. Further, while repression has salient costs, it may also reduce the likelihood of all opposition activity in the short-term and the level of nonviolent protest overall. ${ }^{23}$ As such, facing budget constraints and an inability to reallocate resources, leaders may choose to engage in

\footnotetext{
${ }^{20}$ Murdie and Peksen 2013; Blanton and Blanton 2007; Barry, Clay, and Flynn 2013; Neumayer 2003; Lebovic and Voeten 2009; Ron, Ramos, and Rodgers 2005.

${ }^{21}$ Lichbach 1987; Mason and Krane 1989; Moore 1998; Mason 2004; Bell et al 2013; Sullivan 2014.

22 Poe 2004.

23 Rasler 1996; Regan and Norton 2005.
} 
repression and may even be capable of gaining at least a short-term respite from their opposition as a result.

This possibility becomes more likely when one begins to consider the means and flexibility required to engage in alternative responses to dissent. For example, consider the strategy of accommodation. Effective accommodations can be expected to reduce dissent by ameliorating the grievances of those acting against the state. ${ }^{24}$ However, the "demand" for government action in the form of demands placed on the state, and thus, in some broad sense, existential threats to the government, exists in all countries at all times, albeit to varying degrees. Given that policies and institutions have, by their very nature, distributive consequences, governments that seek to accommodate demands, but do not have access to external resources, must allocate funds to their accommodation that, in the absence of the demand, would have been placed elsewhere. ${ }^{25}$ In equilibrium, governments are expected to spend their funds in such a way that keeps them in power. ${ }^{26}$ Thus, if government leaders are beholden to their winning coalition, many of the government's funds can be expected to be distributed to that coalition's members and their demands in equilibrium. If leaders fail to satisfy their coalition's demands, internal rivals are likely to challenge their tenure. Therefore, if a government with a fixed budget seeks to accommodate a demand from a group outside of its winning coalition, the government will likely be required to redistribute funds away from its support base, either through increased taxes or simple redistribution of the state's current revenue. As such, accommodation could be quite dangerous for the current government's continued political survival and thus, is a quite costly, potentially inviable, policy option. ${ }^{27}$ Given the relative costs of the two strategies, credit constrained governments may feel that they have little choice but to respond to internal threats with

\footnotetext{
24 Mason 2004.

${ }^{25}$ See Knight 1992 on the redistributive nature of institutions.

${ }^{26}$ Bueno de Mesquita et al 2003.

27 The same logic applies to political accommodations. The extension of political rights or autonomy to a group outside a leader's winning coalition is likely to increase threats to power from within a leader's winning coalition. Extending rights to the disenfranchised reduces the relative power of the existing coalition and may lead to policies aimed at greater economic benefits for the newly empowered group (Gandhi 2008). Without access to external resources to compensate those harmed by accommodation with side payments, leaders may face competition from within (Bueno de Mesquita et al. 2003).
} 
repression, rather than with more costly alternatives that require a greater degree of fiscal flexibility, such as accommodation.

However, given access to credit, the trade-off between the current distribution of resources and the ability to meet dissent with strategies other than repression is greatly reduced. Returning to the example of accommodation, access to affordable credit grants governments with a unique capability to accommodate demands from groups outside their winning coalition without engaging in redistribution. ${ }^{28}$ In this case, states must simply be willing to take on a higher debt burden in the long term in exchange for a short-term (and potential long-term) reduction of threat. Thus, creditworthy states should be more likely to engage in accommodation than their credit-poor counterparts. This strategy may increase a country's debt burden in the long-term and ultimately risk a country's creditworthiness if the leader's time horizon is sufficiently short. ${ }^{29}$ However, at the time when a leader faces a threat, credit has clear advantages. While incurring debt is not entirely costless, a leader's desire to remain in office will likely trump any concern for a debt that they or their successor may encounter down the road. Furthermore, as a state's creditworthiness increases, the distance between loan disbursement and repayment widens. As a result, we anticipate that the leaders of creditworthy states will have a greater flexibility in their policy choices and will feel less pressure to rely solely on repression to respond to demands.

\section{Sovereign Creditworthiness \& Repression as a Result of Agency Loss}

Even state leaders that choose to respect physical integrity rights may find it difficult to do so if they lack access to resources outside of traditional tax and non-tax revenues. In the absence of external resources to aid the state, governments may find themselves incapable of fulfilling their obligations any time revenues fall below expected levels. By necessity, government leaders delegate responsibility for dealing with citizens to many different state agents. As such, the responsibility for limiting the government's use of physical integrity rights violations often falls to soldiers and police officers. In such principal-agent relationships, agents should be expected to seek the highest return on the

\footnotetext{
28 If citizens hold perfect information and do not discount the future, some may save in the present for the payment of future taxes necessitated by debt. This would reduce the political advantages of borrowing. However, empirical and experimental research finds little support that economic actors internalize the cost of future repayment or increase present savings as sovereign debts rise (Seater 1993, Ricciuti \& DiLaurea 2003). 29 Oatley 2010.
} 
least effort allowable by the principal's monitoring and incentive structures, while the principal is attempting to ensure the best outcome possible given his or her preferences. ${ }^{30}$ However, monitoring agents and providing incentives are both costly activities. If the government lacks resources to monitor and reward agents, it stands to reason that the behavior of those agents will become increasingly distant from the preferences of their government principals as their interests diverge. ${ }^{31}$ Poorly paid state agents are likely to abuse their power to gain greater rewards, particularly if monitoring is inadequate. Indeed, even state agents that are well-paid are likely to abuse their powers if the monitoring regime is fairly weak and repression is the optimal choice for pursuing the agent's, rather than the government's, preferences.

Based on this argument, it is reasonable to suggest that government leaders do not choose or command every repressive action in which their agents engage; state agents can violate citizens' rights without government leaders' consent and, sometimes, against their will and interests. As a result, if a state lacks access to external resources, any event that leads revenues to fall below expected levels is likely to result in (1) a decreased ability of the state to reward agents for their service, (2) decreased state capability to monitor the behavior of its agents, and (3) increased discretion on the part of agents. ${ }^{32}$ With increased discretion and decreased monitoring and rewards, agency loss is inevitable, resulting in an increased likelihood that state agents engage in repressive practices, even if the government leadership would prefer restraint. As governments face economic downturns, the ability to pay government employees diminishes as both revenue declines and efforts to increase revenue are met with political opposition.

In many cases, governments that could not smooth government spending with sovereign credit have either reduced or deferred the wages of government employees, and, in response, security agents used their repressive capacity to loot citizens in order to offset lost wages. For instance, in the face of revenue shortfalls in the early 1990s, Zaire decided to pay its soldiers in bank notes that would not be accepted by shopkeepers due to the central bank's insolvency. Consequently, soldiers responded to the absence of income and declining

\footnotetext{
30 Kiewiet and McCubbins 1991, 24.

${ }^{31}$ Englehart 2009.

32 Policzer 2004; Abouharb and Cingranelli 2006; Englehart 2009; Cingranelli, Fajardo-Heyward, and Filippov 2014.
} 
living standard by using their coercive means for personal ends. ${ }^{33}$ Similarly, as Uruguay's credit rating dropped in early 2002, primarily as a result of Argentina's economic crisis ${ }^{34}$, conditions in Uruguay's prisons deteriorated due to budget shortfalls. ${ }^{35}$ By 2003 , the prisons were suffering from understaffing, corruption, and physical violence, and beatings at the hands of prison guards had become routine. ${ }^{36}$ Whereas, in the past, the government had the resources to investigate accusations of wrongdoing by state agents in the prison and to ensure acceptable prison conditions, the loss of access to affordable credit led to budget woes, which eventually contributed to an increased use of torture in Uruguay's prisons.

Overall, access to credit should improve the state's ability to both reward and monitor its agents, bringing their activities closer in-line with those preferred by the state. States with access to credit can maintain stronger control of their agents during times of reduced government revenues than their non-creditworthy counterparts and are always capable of exerting better control of their agents than their immediate revenue would allow.

\section{Observable Implications}

Overall, the arguments laid out above lead us to believe that states with greater access to affordable credit will engage in fewer abuses of physical integrity rights. As such, we posit our primary hypothesis, i.e. the Sovereign Creditworthiness Hypothesis (H1):

H1: The higher (lower) a state's creditworthiness, the greater (lower) its respect for physical integrity rights.

In particular, we have argued that leaders of credit-constrained governments (1) will find it difficult to deal with internal threats to their political survival via means other than through violations of physical integrity rights and (2) will find it difficult to restrict their agents' abuses of physical integrity rights in the face of revenue fluctuations. Access to credit helps to ameliorate each of these problems and thus, should reduce the government's, as well as its agents', reliance on repression. As such, we also state two auxiliary hypotheses, i.e. the Government Decision Making Hypothesis (H2) and the Agency Loss Hypothesis $(H 3)$, respectively:

\footnotetext{
33 Bates 2008.

${ }^{34}$ Rich 2002.

35 US Department of State 2003.

36 US Department of State 2004.
} 
H2: The negative effect of violent dissent on a government's respect for physical integrity rights diminishes as a state's creditworthiness increases.

H3: The negative effect of revenue shocks on respect for physical integrity rights diminishes as a state's creditworthiness increases.

\section{Data and Methods}

To test our primary hypothesis (H1), we estimate the effect of creditworthiness on a state's respect for physical integrity rights in a cross-sectional time-series framework that employs data from 157 states from 1982-2009. To test the remaining hypotheses, we employ multiplicative interaction models to assess how creditworthiness alters the effects of violent dissent and tax revenue shocks on a state's use of repression. In this section, we describe the data we use in these tests.

Physical Integrity Rights

We operationalize government respect for physical integrity rights using the Physical Integrity Rights Index and its component parts, obtained from the CIRI Human Rights Data Project. ${ }^{37}$ The CIRI Project generates individual measures of the degree to which governments violate their citizens' rights not to be subjected to torture, extrajudicial killing, political imprisonment, and disappearance based on information contained in the U.S. State Department's annual Country Reports on Human Rights Practices and Amnesty International's Annual Report. Each of these measures varies from 0 (no respect) to 2 (full respect). Finally, summing the individual measures creates the Physical Integrity Rights Index, producing a nine-value aggregate measure. Thus, lower scores reflect less government respect for physical integrity rights (i.e. higher levels of state repression). In our analysis, we estimate the influence of creditworthiness on both the index of physical integrity rights and each of its constituent parts. Doing so adds greater nuance to our understanding of the hypothesized relationship and also addresses concerns related to the use of the additive index as a dependent variable. ${ }^{38}$

\section{Creditworthiness}

Next, we consider a state's creditworthiness. A state's access to credit and the interest that it pays on loan obligations are determined by many factors that are all related to

\footnotetext{
${ }^{37}$ Cingranelli and Richards 2011.

38 Wood and Gibney 2010.
} 
the fundamental enforcement problems inherent in sovereign borrowing. Since creditors have little recourse to recoup funds if a sovereign repudiates its debt, information regarding the state's ability and willingness to repay (i.e. its default risk) is central to the initial bargain between creditors and sovereigns over the decision to extend credit and the rate of interest. Previous literature suggests a number of factors that inform this bargain and correlate with default risk. They include a state's reputation for repaying debts, existing debt burden, political institutions and stability, economic development, foreign reserves, trade balance and other macroeconomic factors. ${ }^{39}$ While previous research indicates that these variables matter, it is not clear that each factor matters equally across states. For example, states that have a stellar reputation for repaying loans and those that establish a credible commitment to repay can maintain a debt burden that would disqualify other states from new loans. As many European states have demonstrated in the aftermath of the "great recession," governments may see an increase in borrowing costs for years when investor nerves are shaken, even while those states maintain a high level of development. Consequently, relying on one of the many factors correlated with the distinct concept of creditworthiness is difficult without introducing considerable bias.

Credit ratings, in contrast, reflect the default risk assessment of credit rating agencies and creditors. Readers are probably familiar with rating agencies that assign letter grades that correspond with their assessment of a security, firm, or government's investment outlook. In practice, these ratings are used to inform investment decisions. Because these ratings are market generated, they are reliable indicators upon which to measure a state's ability to raise capital on international markets and thus, its fiscal flexibility. Furthermore, these ratings are frequently used in empirical research that aims to predict the decisions of ratings firms and identify the correlates of creditworthiness. ${ }^{40}$ Unfortunately, these measures are unsuitable for the broad cross-sectional time-series framework used for much quantitative human rights research. The grades assigned to governments by firms such as Standard \& Poor's, Moody's, and Fitch offer poor coverage and suffer substantial selection bias. Assessment of most emerging market and developing states begins in the 1990s despite the frequent activity of these states in credit market since the 1960s. Furthermore, states that are small, and

\footnotetext{
${ }^{39}$ Cantor and Packer 1996; Saiegh 2005; Tomz 2007.

40 Archer, Biglaiser and DeRouen 2007; Beaulieu, Cox and Saiegh 2012; Saiegh 2005.
} 
therefore, do not warrant the interest of creditors, are absent from the sample despite having a potentially high creditworthiness. Fortunately, another indicator of default risk is available.

To measure a state's creditworthiness and changes in creditor perceptions, we utilize Institutional Investor Country Credit Ratings (IIR). The ratings offer greater coverage (157 states - listed in the Supplementary Appendix) and variance than the ratings firms' letter grades and have been used in both economics and political science to capture sovereign default risk. ${ }^{41}$ The measure spans from 0-100 (100 being the most creditworthy) and represent the anonymous opinions of experts in securities firms and investment banks. Their individual responses are then weighted by their firm's holdings of government debt. ${ }^{42}$ The data have been published twice a year since 1980, including states at every level of development, and thus providing a broad temporal and cross-national sample to test our hypotheses. The measure is highly correlated with the ratings published by rating agencies where observations overlap (at .96), indicating that the measure is not out of line with the more familiar rating agency data. We average the bi-yearly scores to create an annual indicator and then lag this measure one year to minimize the risk of endogeneity. Next, we discuss several controls related to both a government's respect for physical integrity rights and a country's creditworthiness.

\section{Additional Covariates}

The human rights research program indicates that regime type and economic development are strongly related to physical integrity rights. ${ }^{43}$ Theory states that a high standard of living and political avenues for political representation will both reduce citizen grievances and impose constraints on a government's ability to respond to political demands with violence. These two variables also have a positive relationship with sovereign creditworthiness. In regards to economic development and economic growth, the logic is simple. Those states that generate greater income have a greater ability to repay loans and therefore, creditors are more willing to extend loans. ${ }^{44}$ There is greater dispute over the roles of political institutions and a state's creditworthiness. Scholars have argued that democratic institutions provide a mechanism by which states can credibly commit to repay sovereign

\footnotetext{
41 Ahlquist 2006; DiGiuseppe, Barry and Frank 2012; Reinhart et al. 2003.

42 D'Ambrosio 2005.

43 Davenport and Armstrong 2004; Poe, Tate, and Keith 1999; Richards, Gelleny, and Sacko 2001.

${ }^{44}$ Cantor and Packer 1996.
} 
loans. ${ }^{45}$ While theoretically compelling, empirical investigation of the relationship in the late twentieth century presents mixed findings. ${ }^{46}$ However, other research indicates that it is not regime type, but rather more dynamic political factors, such as regime durability and partisan politics, that influence a country's credit rating. ${ }^{47}$

To isolate the influence of creditworthiness' variance on a state's respect for physical integrity rights, we control for the influence of political institutions and economic development with several variables. As with standard models predicting physical integrity rights, we include the natural log of gross domestic product per capita (GDPpc) ${ }^{48}$ and the 21-point Revised Combined Polity Score ${ }^{49}$ to control for development and democracy, respectively. Furthermore, we include a lagged measure of economic growth to control for a state's recent economic fortunes. ${ }^{50}$ States that experience poor growth may experience increased political demands driven by economic grievances and also declining credit terms as creditors may doubt a government's ability to continue scheduled loan repayments. To control for the stability of the government, we include Polity's measure of regime durability that indicates the years since a state experienced an institutional regime change, as indicated by a three-point change in Polity within a three-year period. ${ }^{51}$ We also run a number of diagnostic tests to assure that the correlation of development and democracy with creditworthiness does not bias our estimates.

We also control for war on location with a dummy variable that captures whether a state is currently experiencing a war within its borders, based on data from Version 4-2011 of the UCDP/PRIO Armed Conflict Dataset. ${ }^{52}$ States that fight either international or internal wars within their borders have a substantially larger probability of repression. ${ }^{53}$ Furthermore, war is likely to shape creditors perceptions of a state's ability and willingness to repay loan obligations. Given that previous research has found states with larger populations

\footnotetext{
45 North and Weingast 1989.

46 Archer, Biglaiser and DeRouen 2007; Beaulieu, Cox and Saiegh 2012; Saiegh 2005.

${ }^{47}$ Vaaler, Schrage and Block 2006.

${ }^{48}$ Hesten, Summers, and Aten 2011.

${ }^{49}$ Marshall, Jaggers, and Gurr 2011.

${ }^{50}$ Hesten, Summers, and Aten 2011.

51 Marshall, Jaggers, and Gurr 2011.

52 Gleditsch et al. 2002.

${ }^{53}$ E.g. Bell, Clay, and Murdie 2012; Poe, Tate and Keith 1999.
} 
likely to engage in higher levels of physical integrity rights abuse, we also include the natural $\log$ of the state's population. ${ }^{54}$ Lastly, we include a lagged dependent variable (LDV) on the right hand side of the equation. Theoretically, there is good reason to suspect that previous repression will influence current repression. Empirically, the lagged dependent variable addresses concerns of serial correlation, effectively models the change in physical integrity rights, and allows for estimates of the long-term effects of the independent variables on our outcome. We provide the summary statistics for the variables discussed in the Supplementary Appendix.

\section{Empirical Analysis}

Table 1 presents the results of three linear models in which we treat the ordinal outcome of the 9-value Physical Integrity Rights Index as a continuous variable and assess the additive impact of a country's Institutional Investor rating (IIR) to test our first and primary hypothesis. Model 1 reports the estimated coefficients from a pooled sample. Model 2 includes country fixed-effects to address potential omitted variable bias and assess the within panel significance of credit rating. ${ }^{55}$ Model 3, which we discuss in more detail below, addresses the potential for an endogenous relationship.

\footnotetext{
54 Henderson 1993; Poe, Tate, and Keith 1999; Richards, Gelleny, and Sacko 2001; Hesten, Summers, and Aten 2011.

55 In Models 1 and 2, we report panel-corrected standard errors to address concerns of correlated error terms among panels that may bias the standard errors (Beck 2011).
} 
Table 1: The Influence of Credit Rating on Physical Integrity Rights (Linear Models)

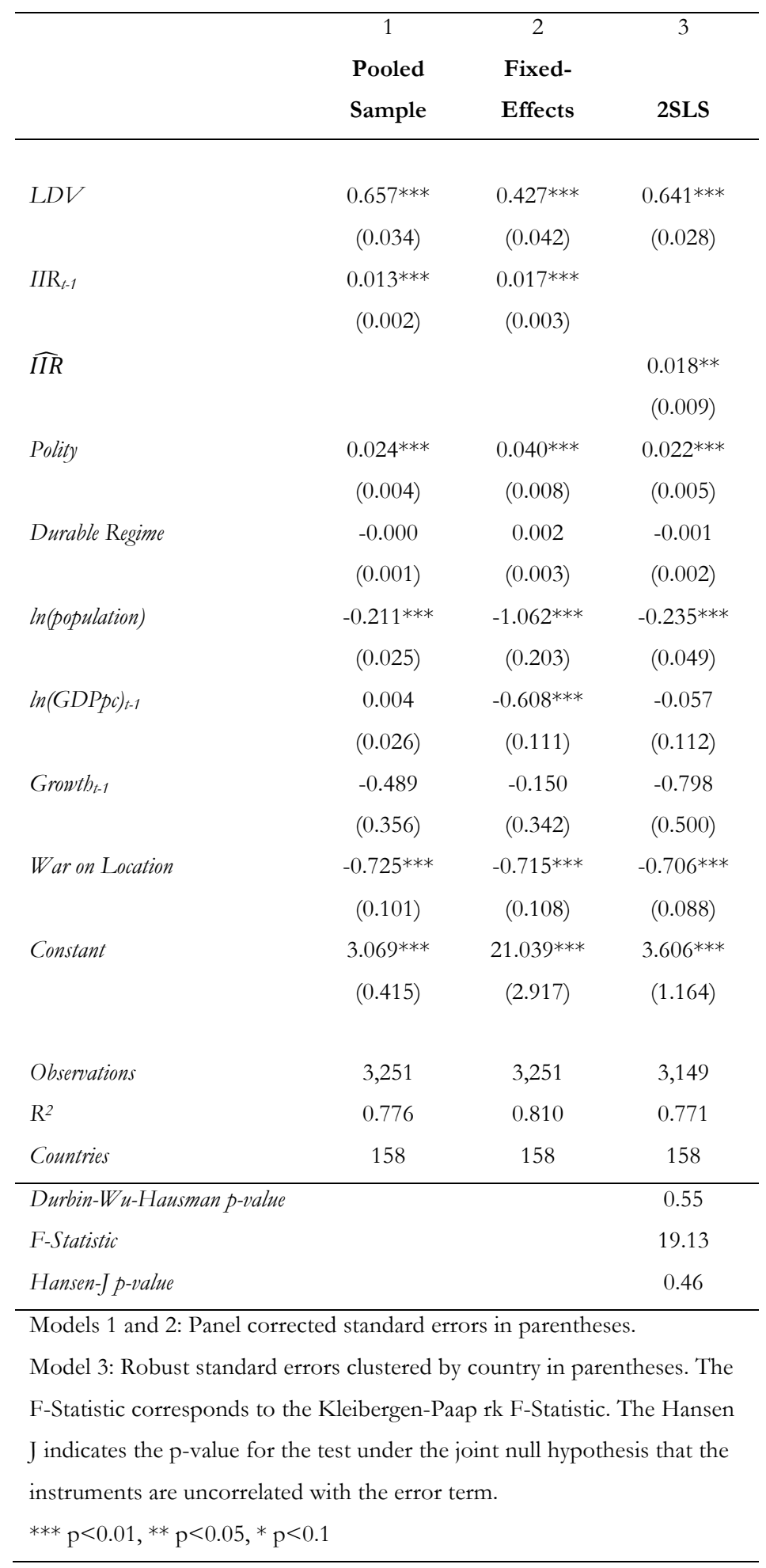


Models 1 and 2 indicate that the IIR coefficient is positive and significant in both the pooled and fixed-effects specifications. This provides initial support for our primary hypothesis. Furthermore, the robustness to fixed-effects in Model 2, indicates that the effect of creditworthiness is temporal and not solely the product of cross-national variance. In other words, when a country's credit terms increase (decrease), there is a positive (negative) change in respect for physical integrity rights within a state. Additionally, by controlling for several economic factors and estimating fixed-effects, the results are consistent with the assertion that the effects of sovereign creditworthiness are distinct from the slow moving, largely cross-national, effects of economic development, regime type, and unobserved state specific factors related to a government's capacity to uphold respect for physical integrity rights. Beyond statistical significance, we next consider IIR's notable substantive effect.

Because we included a lagged dependent variable in our equation, it is possible to assess the long-run substantive effect of the covariates in our model. ${ }^{56}$ We employ a helpful approach suggested by Williams and Whitten to assess the uncertainty around the long-term effects of a country's Institutional Investor rating (IIR) and Polity score with dynamic simulations. Using the estimates of Model 1, Figure 1 plots the $95 \%$ confidence intervals around the dynamic simulations of four different scenarios over ten-years based on the estimates of Model 1. The capped black lines represent the two scenarios where IIR is held a standard deviation above or below the mean. Similarly, the gray lines capped by an " $x$ " demonstrate the long-term effect of regime type when Polity is at its minimum and maximum. Furthermore, each scenario begins with the lagged value of the Physical Integrity Rights Index set at the sample's mode (5) and adjusts to the previous year's estimate as the simulation progresses. We hold the remaining variables constant at their mean or modal values.

Holding aside the Polity scenarios for a moment, Figure 1 allows us to interpret the statistical significance of the IIR scenarios in several ways. First, the bounds of the two IIR scenarios do not overlap. This demonstrates the statistical significance of the immediate effect. Furthermore, the confidence intervals begin to exceed the bounds of previous values

\footnotetext{
${ }^{56}$ The long run effect can be calculated with the following equation: $L T E_{x}=\hat{\beta} /(1-\widehat{\phi})$, where $\hat{\beta}$ is the coefficient of the relevant independent variable and $\hat{\phi}$ is the coefficient of the LDV (Williams and Whitten 2012, 686).
} 
as time progresses within each scenario, indicating the significance of the long-term effect. The substantive long-run effect between the scenarios is also informative. Not only do the two scenarios fail to overlap, the gap between them increases far beyond the initial effect evident in the reported coefficient. Consequently, the simulations demonstrate the full impact of creditworthiness that would be ignored if traditional methods were applied. Substantively, this demonstrates how a state's fiscal flexibility to manage domestic dissent has a lasting impact.

Figure 1: Simulated Long Term Effects of IIR and Polity on Physical Integrity Rights

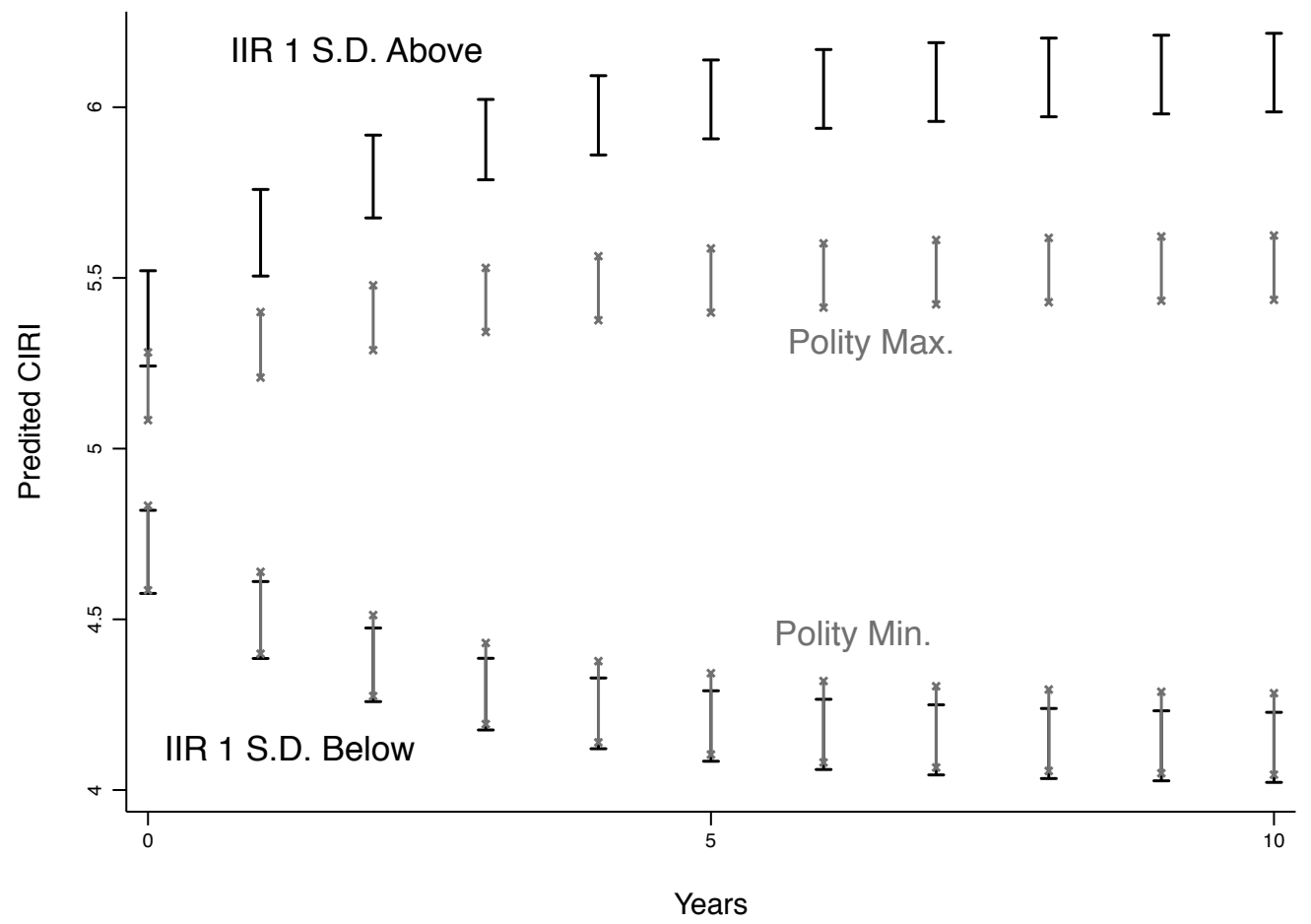

Note: The bars represent the $95 \%$ confidence interavals around the simulated means of each scenario.

Figure 1 also demonstrates the considerable long-term effect of regime type, which we employ as a benchmark to assess the substantive importance of creditworthiness. The effect of creditworthiness appears to exceed the substantive effect of regime type in the immediate and long-run, even while observing a two standard deviation difference in IIR beside the minimum and maximum values of the Polity index. Evidence of a relationship between regime type and respect for human rights is a widely cited finding that has 
commanded the attention of scholars and policymakers alike. ${ }^{57}$ Consequently, we argue that the comparable influence of creditworthiness demands similar appreciation by researchers and policymakers.

Next, we consider that the evidence presented thus far is the result of an endogenous relationship between a country's Institutional Investor rating (IIR) and respect for physical integrity rights despite the fact that we lagged IIR by one-year. It is conceivable that a state's respect for physical integrity rights influences creditor perceptions of its default risk. To address this concern, we employ a two-stage least squares (2SLS) estimation, instrumenting IIR with the separate counts of external debt crises experienced in a country's geographical region in the observed year and the year prior. These are strong and credible instruments because they capture an important external influence on a state's creditworthiness. Credit markets exist under substantial information asymmetry in which creditors have much less information regarding the ability of a state to repay its debts than the state itself. ${ }^{58}$ Thus, creditors often rely on informational cues such as the behavior of neighboring states to assess default risk. ${ }^{59}$ This informational reliance on neighboring states can contribute to contagion that influences bond spreads or aids the spread of debt crises from one state to another. We exploit the exogenous contagion process here to satisfy the exclusion restrictions necessary for instrumental variable estimation. We rely on Reinhart and Rogoff's coding of debt crises and the United Nation's classification of 21 different sub-regions to compile the count of external and domestic debt crises. ${ }^{60}$

Model 3 displays the results of the second stage of the 2SLS regression. First, the Durbin-Wu-Hausman test of endogeneity indicates that we cannot reject the null hypothesis that IIR is exogenous and, thus, the OLS estimates are more efficient. Second, the first stage indicates that the instruments are strongly correlated with IIR rating. Next, a high F-statistic and a failure to reject the null Hansen $\mathrm{J}$ indicate the instruments are not weak and are valid.

\footnotetext{
${ }^{57}$ E.g. Davenport and Armstrong 2004; Poe, Tate, and Keith 1999.

58 Drazen 2001.

${ }^{59}$ Brooks, Cunha and Mosley ND.

${ }^{60}$ If a state experiences its own debt crisis, we subtract 1 from the respective variable. An external debt crisis is defined as a sovereign default or "the failure to meet a principal or interest payment on a due date" (Reinhart and Rogoff 2008, 11). In addition to the 2SLS estimates, we also ran robustness checks with 2, 3 and 4 years lags of IIR. In each instance, the results are largely similar in tests of both hypotheses.
} 
Lastly, the coefficient for instrumented IIR is positive and significant and also larger than both previous models. Overall, this leads us to conclude that our results have not been driven by endogeneity between IIR and the Physical Integrity Rights Index, and thus, higher credit ratings appear to yield higher government respect for physical integrity.

The models presented in Table 2 further demonstrate the robustness of our results and shed additional light on the hypothesized relationship. First, since the CIRI index is a discrete ordered variable, the data are likely to be heteroskedastic, and the estimates may be misleading if the distances between each rank on the index are not similar. To address this, we demonstrate in Model 4 that a random-effects ordered probit model generates results consistent with the linear specifications. Next, previous work has argued that aggregate measures of human rights practices may obscure important differences between various repressive strategies, ${ }^{61}$ and recent studies have demonstrated that some factors may yield varying effects according to the particular repressive strategy utilized. ${ }^{62}$ As such, models 5-8 test our primary hypothesis using the constituent parts of the CIRI index. Given that each variable has only three values, an OLS model is especially inappropriate and, thus, we exclusively rely on random-effects ordered probit estimates. The models estimate a specification similar to Model 4 substituting one of the component parts for the overall CIRI index. Across each model, the coefficient of IIR is positive and significant, demonstrating that creditworthiness is related to each of the components of the CIRI index. To assess the substantive effect of the Institutional Investor ratings (IIR) on each of the four CIRI components, Figure 2 presents four panels, each illustrating the $95 \%$ uncertainty around the predicted probability of the lowest outcome (black shaded area - frequent use of killings, disappearances, political imprisonment or torture) and the highest outcome value (grey shaded area - no use of killings, disappearances, political imprisonment or torture) on the 0 2 scale for each CIRI component from the respective estimates of models 5-8. In each case, we hold the remaining variables at either their means or modes, and the lagged dependent variable at 1 (occasional use of killings, disappearances, political imprisonment or torture).

\footnotetext{
${ }^{61}$ McCormick and Mitchell 1997.

${ }^{62}$ E.g. Abouharb and Cingranelli 2006; Conrad and DeMeritt 2014.
} 


\begin{tabular}{|c|c|c|c|c|c|}
\hline \multicolumn{6}{|c|}{ Ordered Probit Models) } \\
\hline & 4 & 5 & 6 & 7 & 8 \\
\hline & \multicolumn{3}{|l|}{ Phys. Int. } & \multicolumn{2}{|l|}{ Political } \\
\hline & Index & Killings & Disappearances & Imprisonment & Torture \\
\hline \multirow[t]{2}{*}{$L D V$} & $0.504 * * *$ & $0.962 * * *$ & $0.942 * * *$ & $0.944 * * *$ & $1.028^{* * *}$ \\
\hline & $(0.028)$ & $(0.071)$ & $(0.068)$ & $(0.066)$ & $(0.072)$ \\
\hline \multirow[t]{2}{*}{$I I R_{t-1}$} & $0.016^{* * *}$ & $0.021^{* * *}$ & $0.019 * * *$ & $0.013^{* * *}$ & $0.017^{* * *}$ \\
\hline & $(0.003)$ & $(0.003)$ & $(0.003)$ & $(0.003)$ & $(0.004)$ \\
\hline \multirow[t]{2}{*}{ Polity } & $0.032^{* * *}$ & -0.002 & $0.021 * * *$ & $0.074 * * *$ & $0.011 *$ \\
\hline & $(0.006)$ & $(0.006)$ & $(0.007)$ & $(0.007)$ & $(0.006)$ \\
\hline \multirow[t]{2}{*}{ Durable Regime } & -0.001 & 0.000 & 0.002 & -0.001 & -0.000 \\
\hline & $(0.002)$ & $(0.002)$ & $(0.002)$ & $(0.002)$ & $(0.002)$ \\
\hline \multirow[t]{2}{*}{$\ln$ (population) } & $-0.302 * * *$ & $-0.354 * * *$ & $-0.234 * * *$ & $-0.295^{* * *}$ & $-0.285^{* * *}$ \\
\hline & $(0.035)$ & $(0.044)$ & $(0.037)$ & $(0.043)$ & $(0.033)$ \\
\hline \multirow[t]{2}{*}{$\ln (G D P p c)_{t-1}$} & 0.032 & 0.020 & -0.049 & -0.010 & -0.005 \\
\hline & $(0.048)$ & $(0.057)$ & $(0.049)$ & $(0.065)$ & $(0.059)$ \\
\hline \multirow[t]{2}{*}{ Growth $_{t-1}$} & -0.651 & -0.648 & -0.097 & $-1.015^{* * *}$ & -0.532 \\
\hline & $(0.453)$ & $(0.468)$ & $(0.649)$ & $(0.355)$ & $(0.397)$ \\
\hline \multirow[t]{2}{*}{ War on Location } & $-0.539 * * *$ & $-0.458^{* * *}$ & $-0.704 * * *$ & $-0.444 * * *$ & -0.107 \\
\hline & $(0.092)$ & $(0.093)$ & $(0.099)$ & $(0.140)$ & $(0.097)$ \\
\hline Observations & 3,251 & 3,263 & 3,259 & 3,259 & 3,262 \\
\hline \multicolumn{6}{|c|}{ Robust standard errors in parentheses clustered by country } \\
\hline$* * * \mathrm{p}<0.01, * * 1$ & & & & & \\
\hline
\end{tabular}

First, Figure 2 confirms that the effect of IIR is substantively and significantly related to each of the four CIRI components and the prior support for $\mathrm{H} 1$ is not a product of any one component of the additive index. Second, the size of the effect differs across the four panels and amongst the probabilities of the outcomes. While the estimates of the random effects ordered probit do not allow us to say much regarding the direction of the effects (positive or negative change), they do suggest that credit has the largest substantive influence on the use of torture and extrajudicial killings. ${ }^{63}$ There is good reason to suspect that these

${ }^{63}$ IIR has the largest impact on observing $\operatorname{Pr}\left(\mathrm{Y}=2 \mid \mathrm{Y}_{\mathrm{t}-1}=1\right)$ for the torture variable. Our estimates indicate that an increase from the minimum to the maximum represents an approximately $1542 \%$ increase in the probability of observing no use of torture. For the same change IIR is associated with a $567 \%, 256 \%$ and $117 \%$ change for extrajudicial killings, political imprisonment and disappearances respectively. A similar change results in a $-88 \%$, $-98 \%,-87 \%$ and $-88 \%$ change in observing $\operatorname{Pr}\left(\mathrm{Y}=2 \mid \mathrm{Y}_{\mathrm{t}-1}=1\right)$ for the torture, extrajudicial killings, political 
violations are indeed those most likely to be employed in fiscally constrained states. First, agency loss is likely to have a greater effect on torture and extrajudicial killing than on political imprisonment and disappearance. Compared to torture and extrajudicial killing, agents are unlikely to engage in political imprisonment or disappearance without the state's approval, as each of these actions is costly and, in the case of imprisonment, difficult to hide from the government. Torture and extrajudicial killings, on the other hand, are relatively cheap, can often be plausibly denied by poorly monitored government agents, and thus, can be carried out by unsupervised agents easily with a low likelihood of punishment. ${ }^{64}$ Second, because disappearances and political imprisonment often target the few, and thus are likely to have less deleterious effects on violent domestic mobilization, ${ }^{65}$ they are conceivably less likely to be abandoned as tools of governance when states increase their fiscal flexibility to manage domestic dissent. In sum, we believe the findings presented in Figure 2 are consistent with our expectations that governments will be able to avoid the least expensive, and likely least effective, strategies for dealing with dissent when they have access to affordable credit.

imprisonment and disappearances estimates respectively. To capture the direction of IIR's effect, we also run multinomial logit models estimating both the probability of positive and negative change in a state's CIRI score for each form of repression. For each outcome, we found that IIR had a significant negative relationship with the probability an increase in repression. However, IIR only has a significant effect on the probability of decrease in torture and extrajudicial killings. We present the results of these analyses in the Supplementary Appendix.

64 As Mason $(2004,155)$ notes, this is especially likely to hold true for extrajudicial killing in counterinsurgency operations. Given the soldier's primary goal to survive, poorly monitored soldiers in the field are likely to prefer over-caution in the form of "overkilling," i.e. killing any civilian that may potentially pose a threat rather than focusing solely on known insurgents and their supporters.

65 Mason and Krane 1989. 
Figure 2: Predicted Probability of Highest and Lowest Values for Each of the CIRI Components
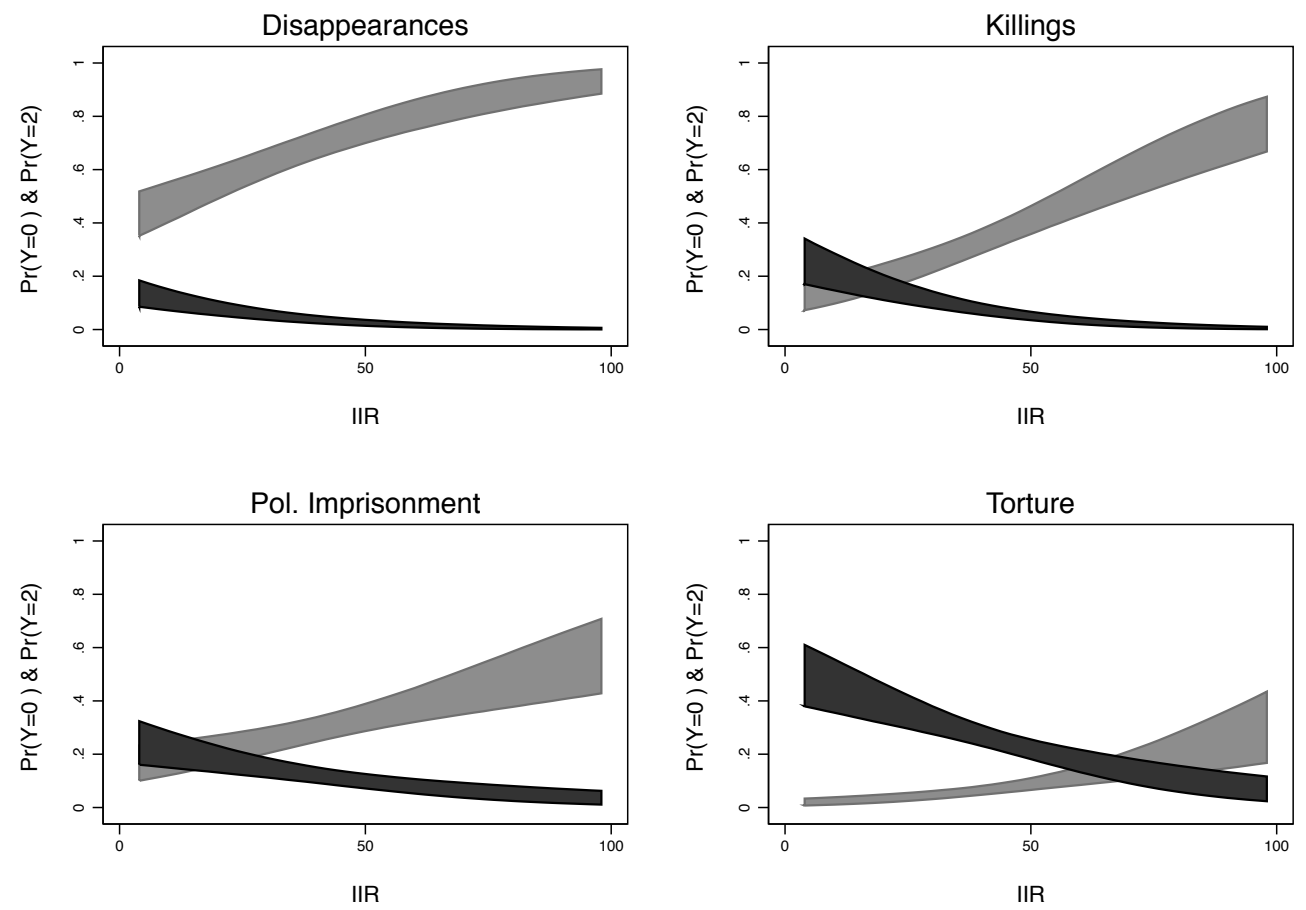

Note: Black shaded areas indicate the $\operatorname{Pr}(\mathrm{Y}=0)$, frequent use of killings, disappearances, political imprisonment or torture. The Grey shaded area indicate $\operatorname{Pr}(\mathrm{Y}=2)$, no use of killings, disappearances, political imprisonment or torture

Beyond creditworthiness, the effects of several control variables in Tables 1 and 2 are also notable. Regime type, population and war on location exert effects largely consistent with previous research. Our estimates indicate that the effects of regime durability and economic growth are not significantly different than zero. More interestingly, economic development was statistically insignificant in most of the models. In fact, in the fixed effects model (Model 2), we find that $\ln (\mathrm{GDP} p$ ) has a negative impact on physical integrity rights. This result gives us pause because it is inconsistent with previous research, which finds strong evidence for a relationship between development and human rights. ${ }^{66}$ Further, it is possible that a high correlation between the $\ln (\mathrm{GDPpc})$ and IIR rating is biasing these results

\footnotetext{
${ }^{66}$ E.g. Abouharb and Cingranelli 2006; Bell, Clay, and Murdie 2012; Poe, Tate, and Keith 1999.
} 
$(0.80) \cdot{ }^{67}$ However, several diagnostic tests indicate that multicollinearity is a minor concern. First, the sample has a mean variance inflation factor of 2.12 , and none of the variables come close to the commonly accepted threshold of 10 . Second, the signs of variables do not change when we estimate our models on randomly split samples. Finally, the significant negative sign in the fixed-effects model persists even if we exclude IIR from the model. We are careful not to claim that creditworthiness deems economic development unimportant for our understanding of human rights practices. There is no doubt that economic development is an important factor in a creditor's assessment of default risk. Thus, economic development may have, at the very least, a substantial indirect influence. However, economic development itself is a blunt indicator that can proxy a number of factors and fails to capture more dynamic relationships between a state's wealth and ability to implement policy. As such, we cautiously note that the finding provides further support for our theory that stresses the importance of government fiscal flexibility rather than aggregate societal or governmental wealth. Leaders of economically developed states are likely to face similar demands for government resources that force them to maximize their income. Without access to credit, leaders of states at all development levels will have a harder time accommodating new demands without drawing resources committed to another segment of society.

Testing the Government Decision Making and Agency Loss Hypotheses

Recall that our theoretical argument asserts that sovereign credit provides leaders with greater resources with which they may both address demands for repression and maintain agency in the face of revenue shocks. In this section, we present empirical support for both mechanisms, corresponding with $\mathrm{H} 2$ and $H 3$, by adding separate variables and their interactions with the Institutional Investor Country Credit Rating (IIR) to our pooled and fixedeffect specifications employed in Table 1. In each estimation, we expect that violent dissent

\footnotetext{
${ }^{67}$ That said, GDP has been found to been statistically insignificant in many recent quantitative analyses of physical integrity rights, particularly when used with country fixed effects (e.g. Cingranelli, Fajardo-Heyward, and Filippov 2014; Hafner-Burton and Tsutsui 2007; Hafner-Burton 2008; Sorens and Ruger 2012).
} 
and revenue shocks are negatively related to physical integrity rights when states have poor credit terms and have less of an impact as a state's credit terms improve. ${ }^{68}$

First, fiscal flexibility helps states augment government resources when they face a demand for repression. As such, governments have additional capital to reduce threats while also minimizing infractions of physical integrity rights. Empirically, this demand for repression is largely unobservable. Creditworthy governments are likely to preempt such demands before they are observable in the form of dissent. However, while adept governments have the ability to preempt violent dissent through accommodation and deterrence, miscalculation and uncertainty will make avoiding all such dissent impossible. If our argument regarding government decision making is correct, a state's creditworthiness should also condition the effect of violent dissent on a state's respect for physical integrity rights. To measure violent dissent, we follow Demerrit and Young by summing the assassination, guerilla tactics and riot variables from the Banks Cross-Sectional Time-Series events dataset. ${ }^{69}$

To offer support for the agency loss mechanism, we estimate the impact of negative changes in tax revenue on a state's CIRI score, conditional on IIR. We expect that negative shocks to tax revenue lead to an increase in repression in states with poor credit terms and that this effect will diminish as a state's ability to borrow increases. To measure tax revenue shocks, we use data from the IMF Government Finance Statistics and construct the percentage change in tax revenue. ${ }^{70}$ Next, we recoded positive changes as zero and inverted the variable so that higher values represent a larger decline in a state's tax revenue. ${ }^{71}$

\footnotetext{
${ }^{68}$ In the Supplementary Appendix (Table 7A), we present a model in which we include both conditional effects in the same model and the corresponding marginal effects. The results largely mirror those presented here and serve to demonstrate that the separate conditional effects are capturing different processes.

${ }^{69}$ Demerrit and Young 2013; Banks and Wilson 2012. This argument also implies that, when facing violent dissent, governments with access to credit will likely run a debt-financed budget deficit to reduce said dissent. According to an additional test, the results of which are presented in Table 6A and Figure 3A in the Supplementary Appendix, this appears to be the case, as violent dissent has a significant, negative effect on creditworthy governments' budget balance, but has no significant effect on the budget balance of the least creditworthy governments.

${ }^{70}$ Morrison 2009.

${ }^{71}$ Because of changes to the manner in which the IMF collects revenue data, this variable is only available until 2001.
} 


\begin{tabular}{|c|c|c|c|c|}
\hline & 9 & 10 & 11 & 12 \\
\hline & Pooled & Fixed- & Pooled & Fixed- \\
\hline & Sample & Effects & Sample & Effects \\
\hline \multirow[t]{2}{*}{$L D V$} & $0.646^{* * *}$ & $0.421 * * *$ & $0.611^{* * *}$ & $0.223^{* * *} *$ \\
\hline & $(0.034)$ & $(0.042)$ & $(0.056)$ & $(0.074)$ \\
\hline \multirow[t]{2}{*}{$I I R_{t-1}$} & $0.013^{* * *}$ & $0.016^{* * *}$ & $0.010^{* * *}$ & $0.022^{* * *}$ \\
\hline & $(0.002)$ & $(0.003)$ & $(0.003)$ & $(0.007)$ \\
\hline \multirow[t]{2}{*}{ Violent Dissent } & $-0.068^{* *}$ & $-0.076^{* *}$ & & \\
\hline & $(0.030)$ & $(0.031)$ & & \\
\hline \multirow[t]{2}{*}{ Violent Dissent ${ }^{*} I R R$} & 0.000 & 0.001 & & \\
\hline & $(0.001)$ & $(0.001)$ & & \\
\hline \multirow[t]{2}{*}{ Revenue Shock } & & & $-3.773^{* *}$ & $-4.810^{* * *}$ \\
\hline & & & $(1.609)$ & $(1.350)$ \\
\hline \multirow[t]{2}{*}{ Revenue Shock*IRR } & & & $0.067^{*}$ & $0.113^{* * *}$ \\
\hline & & & $(0.038)$ & $(0.032)$ \\
\hline \multirow[t]{2}{*}{ Polity } & $0.026^{* * *}$ & $0.040 * * *$ & $0.028 * * *$ & $0.047 * * *$ \\
\hline & $(0.004)$ & $(0.008)$ & $(0.009)$ & $(0.015)$ \\
\hline \multirow[t]{2}{*}{ Durable Regime } & -0.000 & 0.002 & $0.002 *$ & -0.004 \\
\hline & $(0.001)$ & $(0.003)$ & $(0.001)$ & $(0.007)$ \\
\hline \multirow[t]{2}{*}{$\ln$ (population) } & $-0.201 * * *$ & $-1.116^{* * *}$ & $-0.184 * * *$ & $-1.231 * *$ \\
\hline & $(0.025)$ & $(0.204)$ & $(0.036)$ & $(0.533)$ \\
\hline \multirow[t]{2}{*}{$\ln (G D P p c)_{t-1}$} & 0.008 & $-0.633^{* * *}$ & 0.084 & $-1.239 * * *$ \\
\hline & $(0.026)$ & $(0.112)$ & $(0.061)$ & $(0.318)$ \\
\hline \multirow[t]{2}{*}{ Growth $_{t-1}$} & -0.550 & -0.161 & 0.266 & $1.619 *$ \\
\hline & $(0.356)$ & $(0.342)$ & $(0.877)$ & $(0.839)$ \\
\hline \multirow[t]{2}{*}{ War on Location } & $-0.678^{* * *}$ & $-0.709 * * *$ & $-1.001 * * *$ & $-0.668 * * *$ \\
\hline & (0.102) & $(0.109)$ & (0.163) & $(0.206)$ \\
\hline \multirow[t]{2}{*}{ Constant } & $3.039 * * *$ & $22.041^{* * *}$ & $2.496^{* * *}$ & $32.005^{* * *}$ \\
\hline & $(0.410)$ & $(2.939)$ & $(0.776)$ & (7.058) \\
\hline Observations & 3,249 & 3,249 & 1,034 & 1,034 \\
\hline$R^{2}$ & 0.778 & 0.811 & 0.781 & 0.837 \\
\hline Countries & 158 & 158 & 79 & 79 \\
\hline
\end{tabular}

Panel corrected standard errors in parentheses.

*** $\mathrm{p}<0.01,{ }^{* *} \mathrm{p}<0.05, * \mathrm{p}<0.1$

Table 3 presents the results of the four multiplicative models including the violent dissent and tax revenue shock in separate pooled and fixed-effects models. Because of the multiplicative nature of the model, the coefficients for the violent dissent and revenue shock 
variables indicate their sign and significance when IIR is zero. In both their respective pooled and fixed-effects models, violent dissent and tax revenue shock have a negative relationship with the CIRI index as expected. To assess the sign and significance across the range of IIR, we plot the marginal effects in the two panels in Figure 3 for models 10 and 12 respectively. In each panel, the solid line represents the marginal effect, and the dashed lines indicate the 95\% confidence intervals around the effect. The grey bars in the background illustrate the distribution of IIR variable. Substantively, the first panel shows that violent dissent is associated with a decrease in physical integrity rights across a majority of the IIR scale, but becomes statistically insignificant when IIR is above approximately 60. Similarly, a shock to tax revenue has a negative relationship with physical integrity rights when states have a poor credit terms. However, this effect is insignificant for states with an IIR above 30 but then shows a positive effect for highly creditworthy states. This suggests that revenue shocks in states with access to credit may actually improve respect for physical integrity rights. This is an interesting and unexpected finding but does not diminish support for our expectations of credit poor states. Further research is needed, but we speculate that the positive marginal effect is the result of the ability of creditworthy states to engage in countercyclical spending that improves protection for physical integrity rights or reduces demands for repression.

Overall, the results are consistent with the expectations of both conditional hypotheses. Furthermore, additional analyses reveal that regime type and economic development do not have a significant conditioning effect with either violent dissent or revenue shocks. These findings, together with those presented in Table 3, provide strong empirical support for the specific mechanisms that underpin the relationship between physical integrity rights and sovereign creditworthiness. Additionally, these findings further demonstrate the unique role of sovereign creditworthiness in providing states with the fiscal flexibility to manage changes in both threats and revenues without resorting to widespread repression. 
Figure 3: Marginal Effect of Violent Dissent and Revenue Shocks Across IIR
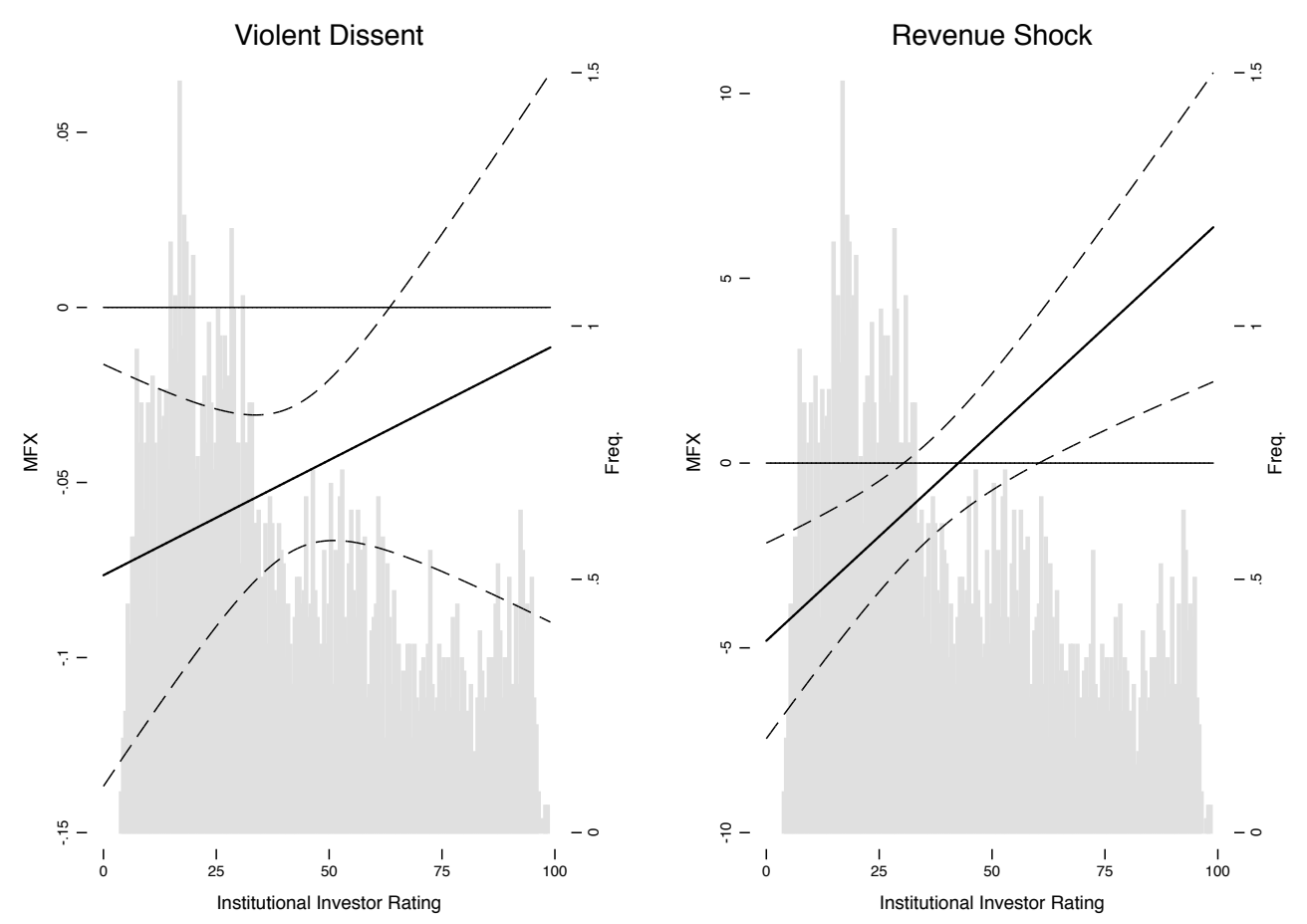

Further Robustness Checks

We acknowledge that readers may question some of the choices we have made regarding the sample and variables used in the primary specification. To allay many of these concerns, we ran various robustness checks, the results of which are available in the Supplementary Appendix. First, the results presented above were run on a sample of both industrialized and developing states. Even though we controlled for development on the right hand side of the equation, the inclusion of highly developed and creditworthy states, which generally have strong human rights practices, could potentially lead to misleading results. To address this concern, we replicate the three specifications reported in Table 1 while excluding states belonging to the Organization for Economic Development and Cooperation (OECD) from the analysis. In each specification, the sign, significance and substantive effect of our central independent variable remain consistent with the results reported above. Next, while we believe the Institutional Investor Rating (IIR) is a superior variable for the analysis here, we also employed a numerical transformation of Standard \& Poor's country credit ratings in tests of both hypotheses. The results largely reflect those presented in the manuscript. 
For various reasons, we omitted several potentially confounding variables from our preferred specification that may influence our results. To address concerns that our main findings are spurious we ran both pooled and fixed-effects analysis with a succession of potentially confounding variables. First, it is possible other time-varying factors related to both a state's capacity to respect physical integrity rights and IIR, not captured by economic development and regime type, are driving the results we presented. Notably, both creditworthiness and respect for human rights require sufficient bureaucratic capacity to collect taxes, accommodate citizens, or monitor the behavior of state agents. To address this concern, we added controls for a state's relative political capacity, which captures the ratio of a state's actual tax collection based on its potential tax collection and its actual collection of tax revenue as a percentage of gross domestic product. ${ }^{72}$ Next, we addressed lower-level domestic conflict and instability by including the Banks weighted domestic conflict index to address whether domestic discontent and the potential demand for repression were influencing both creditworthiness and human rights practices. ${ }^{73}$ As noted above, research indicates that states that draw a large proportion of revenue from non-tax sources (such as oil production) have lower respect for human rights. ${ }^{74}$ Further, by increasing current and future revenues, oil rents may improve a state's ability to borrow. As such, we include Ross' measure of oil rents in our robustness tests. ${ }^{75}$ Next, we control for trade openness, measured as total trade over GDP, to address its role in fostering human rights protection ${ }^{76}$ and the potential that it signals a state's costs for defaulting on sovereign loans. ${ }^{77} \mathrm{We}$ also consider a state's involvement in a World Bank or IMF structural adjustment program and the number of years a state has been involved in such a program, as both have been found to influence human rights practices and both are related to a state's budget constraints. ${ }^{78}$ Finally, we control for the level of market-contracting in a state's economy, which has previously been

\footnotetext{
72 Arbetman-Rabinowitz and Johnson 2009.

73 Banks and Wilson 2012.

${ }^{74}$ DeMeritt and Young 2013.

${ }^{75}$ Ross 2008.

${ }^{76}$ Hafner-Burton 2005.

${ }^{77}$ Rose 2005.

78 Abouharb and Cingranelli 2006.
} 
shown to increase overall respect for physical integrity rights. ${ }^{79}$ The significance and size of the IIR coefficient remains highly stable in both the linear pooled and fixed-effects specifications when including each of these variables. ${ }^{80}$ Overall, the robustness of the results to the inclusions of a battery of potentially confounding variables goes a long way toward demonstrating that our findings are not spurious and that creditworthiness is a unique variable that is conceptually and empirically distinct from other state specific influences on a government's respect for physical integrity rights. The results of these robustness tests are also available in the Supplementary Appendix.

The evidence presented above demonstrates that creditworthiness exerts a significant cross-sectional and temporal influence on repression. We believe this is due to the fiscal flexibility foreign capital provides to the leaders of creditworthy states when they confront new demands that require a government response or experience a decline in government revenue. Leaders with favorable credit terms can avoid neglecting their respect for physical integrity rights when opportunities to employ repression emerge, while fiscally constrained leaders have fewer options and are thus more likely to use repression.

\section{Conclusion}

The protection of physical integrity rights is costly. Indeed, governments require substantial funds to address demands with non-repressive strategies and also maintain control of those put in positions where abuses of power can lead to human rights violations. Given the economic cost of protecting rights, one might conclude that a government's wealth is central to providing these resources. While a country's aggregate resources likely play a role, this reasoning overlooks the politics of redistribution and the political pressures that constrain a government's ability to fund new spending priorities. We contend that researchers should appreciate the role of a government's fiscal flexibility, specifically as afforded by access to private creditors, if they wish to understand when governments choose to protect physical integrity rights. Our empirical analysis is strongly supportive of this claim.

\footnotetext{
${ }^{79}$ Mousseau and Mousseau 2008.

80 Some of the variables we introduced were missing a non-trivial amount of observations. To see if the missing values introduced bias, we ran our baseline model with successive dummy variables indicating if each variable was missing or not. In each case, this dummy was insignificant and the significance of IIR persisted. This suggests that the missing values did not overly bias our robustness checks.
} 
This article holds a number of implications for the study of repression. First, we have drawn attention to variance in the ability of governments to confront new threats and weather changes in revenue and spending demands. This effect, we argue, is distinct from other slow moving indicators of a state's financial resources or capacity. Furthermore, our results demonstrate that the effect of sovereign creditworthiness is on par or greater than variables, like regime type, that are commonly associated with respect for physical integrity rights.

Relatedly, some have argued for the primacy of civil and political rights as "negative" rights that place few obligations on the state, as opposed to the so-called "positive" obligations that accompany economic, social and cultural rights. ${ }^{81}$ However, our study provides further empirical evidence for the stance that state resources are necessary for the protection of physical integrity rights, giving further support to those who argue that the distinction between negative and positive rights represents a largely false dichotomy. ${ }^{82}$ In this regard, our work echoes those that recognize the importance of the principal-agent relationship in the protection of human rights, ${ }^{83}$ but also incorporates the competing demands placed on survival-minded leaders. ${ }^{84}$

Our findings also have implications for arguments linking globalization to human rights practices. Economic globalization has not only increased the availability of goods and capital to private actors around the globe, it has also increased the resources available to governments. Scholars have explored how changing trade patterns, foreign direct investment, and rising income equality have influenced human rights practices. ${ }^{85}$ However, they have not considered how increases in a government's ability to draw on foreign capital may influence a leader's ability to manage domestic challenges without resorting to repression. The evidence here suggests that financial globalization influences repressive behavior in this way and suggests implications for other related political outcomes that are influenced by global economic transactions.

\footnotetext{
${ }^{81}$ Cranston 1973.

82 Donnelly 2003; Shue 1980.

83 Abouharb and Cingranelli 2006; Cingranelli, Fajardo-Heyward, and Filippov 2014; Englehart 2009; Policzer 2004.

${ }^{84}$ Bueno de Mesquita and Smith 2010.

${ }^{85}$ Hafner-Burton 2005; Harrelson-Stephens and Callaway 2003; Richards, Gelleny, and Sacko 2001.
} 
Lastly, while incurring debt may allow states to avoid repression in the short term, the continued reliance on debt, if unproductive, may eventually decrease a state's creditworthiness if these debts are not properly managed and creditors begin to doubt the state's ability to repay. This highlights a longer term dynamic and implication of our argument that we have not yet addressed but deserves further study. 


\section{Works Cited}

Abouharb, M. Rodwan, and David L. Cingranelli. 2006. The Human Rights Effects of World Bank Structural Adjustment, 1981-2000. International Studies Quarterly 50: 233-62.

Ahlquist, John S. 2006. Economic Policy, Institutions, and Capital Flows: Portfolio and Direct Investment Flows in Developing Countries. International Studies Quarterly 50(3): 681-704.

Alesina, Alberto, and Guido Tabellini. 1990. A Positive Theory of Fiscal Deficits and Government Debt. Review of Economic Studies 57: 403-14.

Arbetman-Rabinowitz, Marina and Kristen Johnson. 2009. Relative Political Capacity: Theory, Model, Data \& Updates. Paper Presented at the International Studies Association Conference, San Francisco, 26 March.

Archer, Candace C., Glen Biglaiser, and Karl DeRouen Jr. 2007. Sovereign Bonds and the 'Democratic Advantage': Does Regime Type Affect Credit Rating Agency Ratings in the Developing World? International Organization 61: 341-65.

Banks, Arthur S. and Kenneth A. Wilson. 2012. Cross-Sectional Time-Series Data Archive. Databanks International.

Barro, Robert J. 1979. On the Determination of the Public Debt. The Journal of Political Economy 87(5): 940-71.

Barry, Colin M., K. Chad Clay and Michael E. Flynn. 2013. Avoiding the Spotlight: Human Rights Shaming and Foreign Direct Investment. International Studies Quarterly 57: 532-44.

Bates, Robert H. 2008. When Things Fell Apart: State Failure in Late-Century Africa. New York: Cambridge University Press.

Beaulieu, Emily, Gary W. Cox and Sebastian Saiegh. 2012. Sovereign Debt and Regime Type: Reconsidering the Democratic Advantage. International Organization 66(4): 709-38.

Beck, Nathanial and Jonathan N. Katz. 2011. Modeling Dynamics in Time-Series-Cross-Section Political Economy Data. Annual Review of Political Science 14: 331-52.

Bell, Sam R., David Cingranelli, Amanda Murdie, and Alper Caglayan. 2013. Coercion, Capacity, and Coordination: Predictors of Political Violence. Conflict Management and Peace Science 30(3): 24062.

Bell, Sam R., K. Chad Clay, and Amanda Murdie. 2012. Neighborhood Watch: Spatial Effects of Human Rights INGOs.” Journal of Politics 74 (2): 354-68.

Blanton, Shannon Lindsey and Robert G. Blanton. 2007. What Attracts Foreign Investors? An Examination of Human Rights and Foreign Direct Investment. The Journal of Politics 69(1): $143-55$. 
Brooks, Sarah M., Raphael Cunha and Layna Mosley. Forthcoming. Categories, Creditworthiness, and Contagion: How Investors' Shortcuts Affect Sovereign Debt Markets. International Studies Quarterly.

Bueno de Mesquita, Bruce, and Alastair Smith. 2010. Leader Survival, Revolutions, and the Nature of Government Finance. American Journal of Political Science 54(4): 936-950.

Bueno de Mesquita, Bruce; Alastair Smith, Randolph Siverson, and James D. Morrow. 2003. The Logic of Political Survival. Cambridge: MIT Press.

Cantor, Richard and Frank Packer. 1996. Determinants and Impact of Sovereign Credit Ratings. Economic Policy Review October: 37-54.

Cingranelli, David, and David Richards. 1999. Measuring the Level, Pattern, and Sequence of Government Respect for Physical Integrity Rights. International Studies Quarterly 43 (2): $407-$ 17.

Cingranelli, David L., and David L. Richards. 2011. The Cingranelli-Richards (CIRI) Human Rights Dataset. http://www.humanrightsdata.org (November 28, 2011).

Cingranelli, David L., Paola Fajardo-Heyward and Mikhail Filippov. 2014. Principals, Agents and Human Rights. British Journal of Political Science44(3): 605-30.

Conrad, Courtenay and Jacqueline HR DeMeritt. 2012. Constrained by the Bank and the Ballot: Unearned Revenue, Democracy and State Incentives to Repress. Journal of Peace Research 50(1): 105-19.

Cranston, Maurice. 1973. What are Human Rights? New York: Taplinger.

D'Ambrosio, Mary. 2005. A Less Risky World? Institutional Investor 30 (9): 143-48.

De Soysa, Indra and Eric Neumayer. 2007. Resource Wealth and the Risk of Civil War Onset:

Results from a New Dataset of Natural Resource Rents, 1970-1999. Conflict Management and Peace Science 24: 201-18

Davenport, Christian. 2007. State Repression and Political Order. Annual Review of Political Science 10: $1-23$.

Davenport, Christian and David A. Armstrong II. 2004. Democracy and the Violation of Human Rights: A Statistical Analysis from 1976-1996. American Journal of Political Science 48(3): 538-54. DeMeritt Jacqueline H.R. and Joseph K. Young. 2013. A Political Economy of Human Rights: Oil, Natural Gas, and State Incentives to Repress. Conflict Management and Peace Science 30(2): 99120.

DiGiuseppe, Matthew, Colin M. Barry and Richard W. Frank. 2012. Good for the Money: International Finance, State Capacity and Internal Conflict. Journal of Peace Research 49(3): 391 405. 
DiGiuseppe, Matthew and Patrick Shea. Forthcoming. Sovereign Credit and the Fate of Leaders:

Reassessing the ‘Democratic Advantage.’ International Studies Quarterly.

Donnelly, Jack. 2003. Universal Human Rights in Theory \& Practice. $2^{\text {nd }}$ Ed. Ithaca: Cornell University Press.

Drazen, Allan. 2001. Political Economy in Macroeconomics Princeton, NJ: Princeton University Press.

Dunning, Thad. 2005. Resource Dependence, Economic Performance, and Political Stability. Journal of Conflict Resolution 49 (4): 451-82.

Easterly, William. 2002. How Did the Heavily Indebted Poor Countries Become Heavily Indebted? Reviewing Two Decades of Debt Relief. World Development 30(10): 1677-96.

Englehart, Neil A. 2009. State Capacity, State Failure, and Human Rights. Journal of Peace Research 46 (2): $163-80$.

Erikson, Silja and Indra De Soysa. 2009. A Fate Worse Than Debt? International Financial Institutions and Human Rights, 1981-2003. Journal of Peace Research 46(4): 485-503.

Gleditsch, Nils Petter; Peter Wallensteen, Mikael Eriksson, Margareta Sollenberg and Håvard Strand. 2002. Armed Conflict 1946-2001: A New Dataset. Journal of Peace Research 39(5): 615-637.

Hafner-Burton, Emilie M. 2005. Right or Robust? The Sensitive Nature of Repression to Globalization. Journal of Peace Research 42(6): 679-98.

Hafner-Burton, Emilie M., and Kiyoteru Tsutsui. 2007. Justice Lost! The Failure of International Human Rights Law to Matter Where Needed Most. Journal of Peace Research 44(4): 407-25.

Hafner-Burton, Emilie M. 2008. Sticks and Stones: Naming and Shaming the Human Rights Enforcement Problem. International Organization 62: 689-716.

Harrelson-Stephens, Julie, and Rhonda L. Callaway. 2003. Does Trade Openness Promote Security Rights in Developing Countries? Examining the Liberal Perspective. International Interactions 29: $143-58$.

Hesten, Alan, Robert Summers, and Bettina Aten. 2011. Penn World Table Version 7.0. Center for International Comparisons of Production, Income, and Prices at the University of Pennsylvania, June 2011. https://pwt.sas.upenn.edu/php_site/pwt_index.php (February 7, 2015).

Henderson, Conway W. 1993. Population Pressures and Political Repression. Social Science Quarterly 74 (2): 322-33.

Kiewiet, D. Roderick, and Mathew D. McCubbins. 1991. The Logic of Delegation: Congressional Parties and the Appropriations Process. Chicago: The University of Chicago Press.

Knight, Jack. 1992. Institutions and Social Conflict. Cambridge: Cambridge University Press.

Lebovic, James H. and Erik Voeten. 2009. The Cost of Shame: International Organizations and Foreign Aid in Punishing of Human Rights Violators. Journal of Peace Research 46(1): 79-97. 
Lichbach, Mark Irving. 1987. Deterrence or Escalation: The Puzzle of Aggregate Studies of Repression and Dissent. Journal of Conflict Resolution 31(2): 266-97.

Marshall, Monty G., Keith Jaggers, and Ted Robert Gurr. 2011. “Polity IV Project: Dataset Users' Manual.” http://www.systemicpeace.org/inscr/p4manualv2010.pdf (November 29, 2011).

Mason, T. David. 2004. Caught in the Crossfire. New York: Rowman \& Littlefield Publishers.

Mason, T. David, and Dale A. Krane. 1989. The Political Economy of Death Squads: Toward a Theory of the Impact of State-Sanctioned Terror. International Studies Quarterly 33(2): 175-98.

Mitchell, Neil J., and James M. McCormick. 1988. Economic and Political Explanations of Human Rights Violations. World Politics 40(4): 476-98.

Moore, Will H. 1998. Repression and Dissent: Substitution, Context and Timing. American Journal of Political Science 42(3): 851-73.

Morisson, Kevin. 2009. Oil, Nontax Revenue, and the Redistributional Foundations of Regime Stability. International Organization 63(1): 107-38.

Mousseau, Michael and Demet Yalch Mousseau. 2008. The Contracting Roots of Human Rights. Journal of Peace Research 45(3): 327-44.

Murdie, Amanda and Dursun Peksen. 2013. The Impact of Human Rights INGO Activities on Economic Sanctions. Review of International Organizations 8(1): 33-53.

Neumayer, Eric. 2003. Do Human Rights Matter in Bilateral Aid Allocation? A Quantitative Analysis of 21 Donor Countries. Social Science Quarterly 84(3): 650-66.

North, Douglass C., and Barry R. Weingast. 1989. Constitutions and Commitment: The Evolution of Institutional Governing Public Choice in Seventeenth-Century England. The Journal of Economic History 49(4): 803-32.

Oatley, Thomas. 2010. Political Institutions and Foreign Debt in the Developing World. International Studies Quarterly 54(1): 175-95.

Poe, Steven C. 2004. The Decision to Repress: An Integrative Theoretical Approach to the Research on Human Rights and Repression. Pp. 16-42 in Understanding Human Rights Violations edited by Sabine C. Carey and Steven C. Poe. Burlington: Ashgate.

Poe, Steven C., C. Neal Tate, and Linda Camp Keith. 1999. Repression of the Human Right to Personal Integrity Revisited: A Global Cross-national Study Covering the Years 1976-1993. International Studies Quarterly 43(2): 291-313.

Policzer, Pablo. 2004. How Organizations Shape Human Rights Violations. Pp. 221-238 in Understanding Human Rights Violations edited by Sabine C. Carey and Steven C. Poe. Burlington: Ashgate.

Rasler, Karen. 1996. Concessions, Repression, and Political Protest in the Iranian Revolution. American Sociological Review 61(1): 132-52. 
Regan, Patrick M., and Daniel Norton. 2005. Greed, Grievance, and Mobilization in Civil Conflicts. Journal of Conflict Resolution 49(3): 319-36.

Reinhart, Carmen M., Kenneth S. Rogoff and Miguel A. Savastano. 2003. Debt Intolerance. Brookings Papers on Economic Activity 1:1-62.

Reinhart, Carmen M., Kenneth S. Rogoff. 2008. This Time is Different: Eight Centuries of Financial Folly. Princeton: Princeton University Press.

Ricciuti, Roberto and DAvide DiLaurea. 2003. An Experimental Analysis of Two Departures from Ricardian Equivalence. Economics Bulletin 8(11): 1-11.

Rich, Jennifer L. 2002. Argentina Shakes, Uruguay Rattles. The New York Times 8 May, W1

Richards, David L., Ron Gelleny and David Sacko. 2001. Money with a Mean Streak? Foreign Economic Penetration and Government Respect for Human Rights in Developing Countries. International Studies Quarterly 45(2): 219-39.

Ron, James, Howard Ramos, and Kathleen Rodgers. 2005. Transnational Information Politics: NGO Human Rights Reporting, 1986-2000. International Studies Quarterly 49: 557-87.

Ross, Michael L. Oil, Islam and Women American Political Science Review 102(1): 107-23.

Saiegh, Sebastian M. 2005. Do Countries Have a "Democratic Advantage"?: Political Institutions, Multilateral Agencies, and Sovereign Borrowing. Comparative Political Studies 38(4): 366-87.

Seater, John J. 1993. Ricardian Equivalence. Journal of Economic Literature. 31(1): 142-90.

Shue, Henry. 1980. Basic Rights: Subsistence, Affluence, and U.S. Foreign Policy. Princeton: Princeton University Press.

Smith, Alastair. 2008. The Perils of Unearned Income. Journal of Politics 70(3): 780-93.

Sorens, Jason, and William Ruger. 2012. Does Foreign Investment Really Reduce Repression? International Studies Quarterly 56(2): 427-36.

Sullivan, Christopher Michael. 2014. The (In)effectiveness of Torture for Combating Insurgency. 51(3): 388404.

Tomz, Michael. 2007. Reputation and International Cooperation: Sovereign Debt Across Three Centuries. Princeton, NJ: Princeton University Press.

U.S. Department of State. Various. Country Reports on Human Rights Practices. http://www.state.gov/j/drl/rls/hrrpt/ (October 30, 2012).

Vaaler, Paul M., Burkhard Schrage and Steven A. Block. 2006. Elections, Opportunism, Partisanship and Sovereign Ratings in Developing Countries. Review of Development Economics (10)1: 154-70.

Wibbels, Erik. 2006. Dependency Revisited: International Markets, Business Cycles, and Social Spending in the Developing World. International Organization 60(2): 433-68.

Williams, Laron K. and Guy D. Williams. 2012. But Wait, There's More! Maximizing Substantive Inference from TSCS Models. Journal of Politics 74(3): 685-93. 
Wood, Reed M., and Mark Gibney. 2010. The Political Terror Scale (PTS): A Re-introduction and a Comparison to CIRI. Human Rights Quarterly 32(2): 367-00.

World Bank. 2012. Global Development Finance: External Debt of Developing Countries. Washington D.C.: The World Bank. 